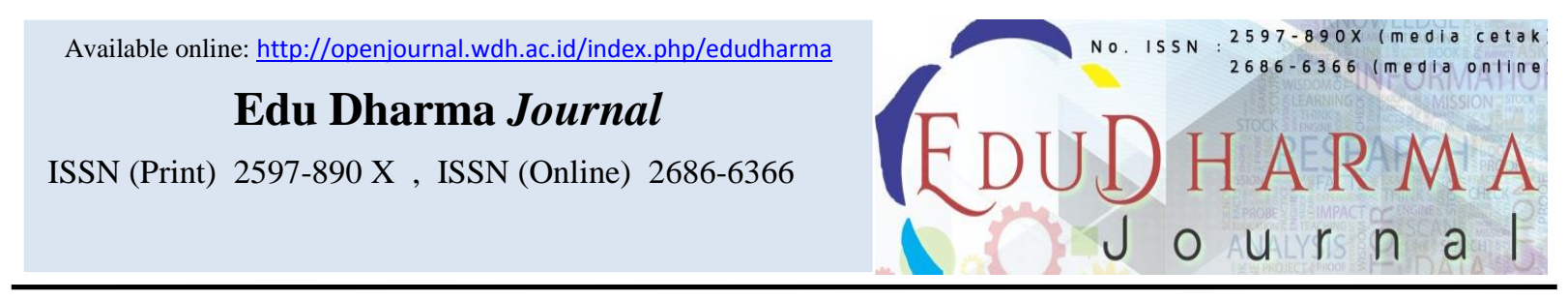

\title{
PENGARUH PEMBERIAN SEDUHAN CAMELLIA SINENSIS TERHADAP TEKANAN DARAH PADA LANSIA DENGAN HIPERTENSI DI POSBINDU ANYELIR KAMPUNG PAKULONAN KABUPATEN TANGERANG
}

\author{
${ }^{1}$ Dewi Fitriani, ${ }^{2}$ Heri Setiawan, ${ }^{3}$ Iif Rifa'i \\ ${ }^{1,2}$ Dosen, STIKes Widya Dharma Husada Tangerang, jl.pajajaran No 1 pamulang, Kota Tangerang Selatan \\ ${ }^{3}$ Mahasiswa STIKes Widya Dharma Husada Tangerang, jl.pajajaran No 1 pamulang, Kota Tangerang Selatan
}

\begin{tabular}{|c|c|}
\hline ARTICLE INFORMATION & $A \quad B S T R A C T$ \\
\hline $\begin{array}{l}\text { Corresponding author: } \\
\text { Dewi Fitriani } \\
\text { dewifitriani@wdh.ac.id }\end{array}$ & $\begin{array}{l}\text { Getting people can be looked at by people over the age of } 60 \text { who have } \\
\text { access to significant economic, psychological, biological and social } \\
\text { dysfunction. The condition of systolic blood preassure } 140 \mathrm{mmHg} \text { and } \\
\text { hypertensive blood preassure great than } 90 \mathrm{~mm} \text { is a condition of the } \\
\text { prevalence in which the nonliving component is identified, called }\end{array}$ \\
\hline $\begin{array}{l}\text { Elderly_1, } \\
\text { Blood Pressure_2, } \\
\text { Sinensis Camelia_3 }\end{array}$ & $\begin{array}{l}\text { polifenol and L-Theanins in wich theneurotransmitter serotonin can } \\
\text { decrease, as the blood preassure on the artery of the research } \\
\text { component purpose to determine if the camellia sinensis could effect } \\
\text { bloodpreassure on lansia with the prevalence of hypertension in the post } \\
\text { of the village of the tangerang district. Research methpds are pre- } \\
\text { experiment with one-grup after-action design. The cheerleading sample } \\
\text { was } 35 \text { people. A total sampel used in collecting research samples. } \\
\text { Research starts in January through to July } 2020 \text {. Wilcoxson test results., } \\
\text { it was found p-value } 0,000 \text { and alfa } 0,05 \text { for sistolic blood pressure, } \\
\text { while for diastolic blood pressure was found p-value }=0,000 \text { and alfa }= \\
0,05 \text { with the average declination of systolic blood pressure } 152,73 \\
\text { mmHg, while the average decline of diastolic blood pressure as many as } \\
88,11 \text { mmHg. It can be concluded that there is impact of giving of } \\
\text { camelia sinensis steeping to the blood pressure on elderly with } \\
\text { hypertension at Anyelir Posbindu, kampung pakulonan, Tangerang } \\
\text { regency. The passing of the camellia sinensis blood preasure on the } \\
\text { elderly is this inconclusive. }\end{array}$ \\
\hline $\begin{array}{l}\text { Kata Kunci: } \\
\text { Lansia_1 } \\
\text { Tekanandarah_2 } \\
\text { Camellia sinensi_3 }\end{array}$ & $\begin{array}{l}\text { A B S T R A K } \\
\text { Lanjut usia dapat diartikan seseorang dengan usia di atas } 60 \text { tahun yang } \\
\text { mempunyai ciri-ciri terdapatnya kelemahan fungsi ekonomi, psikologis, } \\
\text { biologis dan sosial. Kondisi tekanan darah sistolik lebih besar } 140 \\
\text { mmHg Dan ketika tekanan darah diastolik lebih besar dari } 90 \mathrm{mmHg} \\
\text { merupakan kondisi dari hipertensi yangmana komponen penyebab tidak } \\
\text { bisat dikenali, disebut sebagai sekunder, karena menderita penyakit } \\
\text { tertentu. Camellia sinensis mengandung polifenol dan L-theanin yang } \\
\text { mana neurotransmitter serotonin dapat menurun, dengan demikian } \\
\text { tekanan darah pada arteri dipercaya bisa menurun karena komponen } \\
\text { tersebut. Tujuan Riset untuk mengetaui apakah seduhan Camellia } \\
\text { Sinensis bisa berpengaruh terhadap tekanan darah kepada lansia dengan }\end{array}$ \\
\hline
\end{tabular}




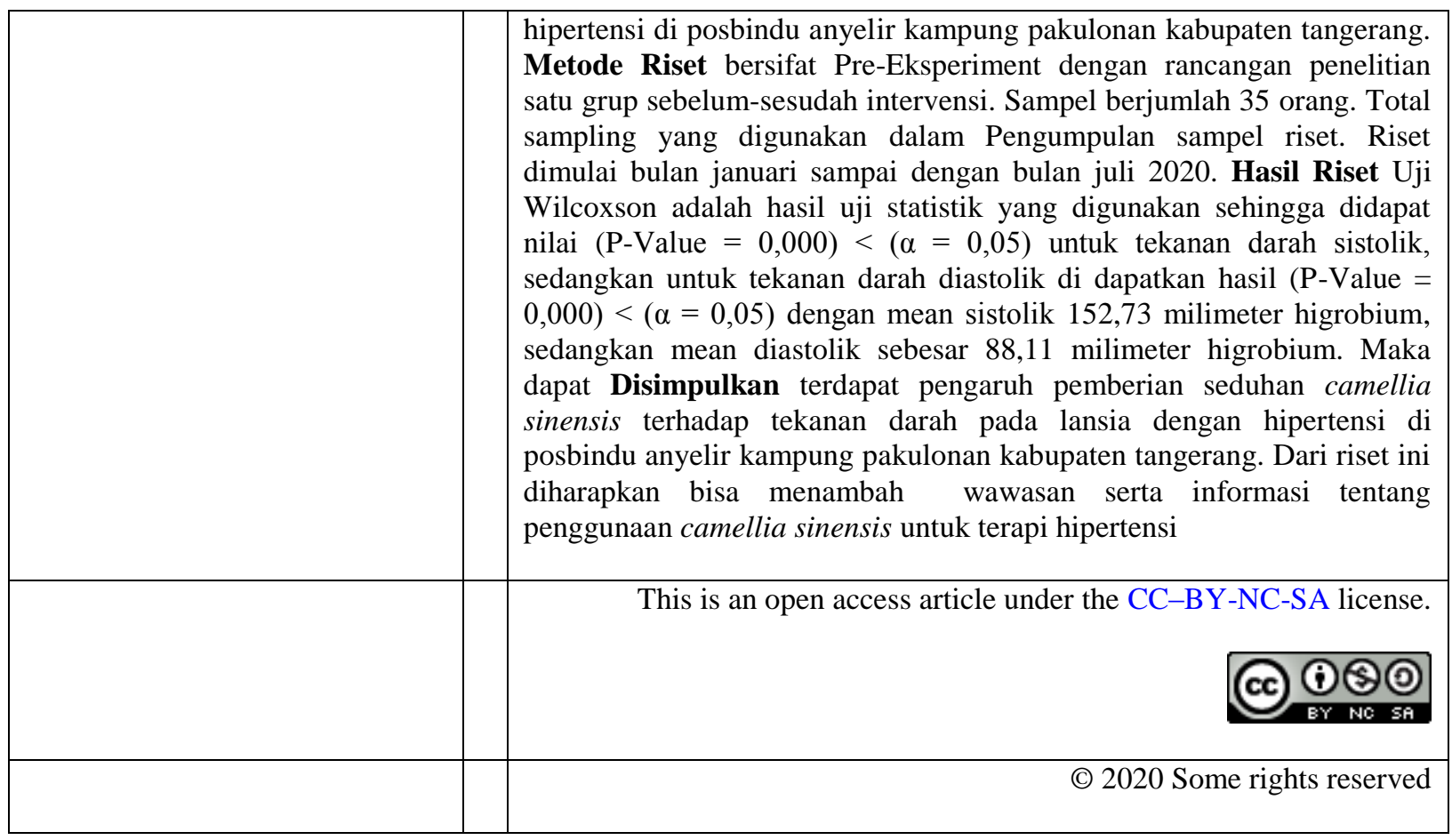


Dewi Fitriani et al_Pengaruh Pemberian Seduhan Camellia Sinensis Terhadap Tekanan Darah Pada Lansia Dengan Hipertensi Di Posbindu Anyelir Kampung Pakulonan Kabupaten Tangerang

\section{PENDAHULUAN}

Usia lanjut memiliki tanda menurunya kelemahan akan kemampuan kognitif diantaranya tidak mudah menerima ide dan hal yang baru, mudah lupa, serta kelemahan akan orientasi terhadap tempat, waktu dan ruang. Adapun hal lainnya yaitu kemunduran secara fisik diantaranya kriput, gigi mulai ompong, kulit yang mulai mengendur, mudah lelah, kurang lincah, dibagian perut terdapat penimbunan lemak dan penglihatan serta pendengaran yang berkurang, Stroke, sendi yang meradang, penyakit paru obstruksi kronik diabetes militus dan hipertensi merupakan penyakit yang sering terjadi pada lanjut usia.

Riskesdas, pada tahun 2018 menjelaskan, semakin meningkat prevalensi tekanan darah tinggi di Indonesia dengan kelompok usia 40-49 tahun (38,8\%). Sebesar 34,11\% merupakan prevalensi penduduk dengan tekanan darah tinggi, pada laki-laki privalensi hipertensi $(31,34 \%)$ lebih rendah dar perempuan $(36,85 \%)$. Data dari hasil studi pendahuluan di posbindu anyelir kampung pakulonan kabupaten tangerang pada bulan Maret 2020, sebanyak 35 Orang lanjut usia menderita hipertensi.
Ketika hipertensi yang tidak terkontrol maka akan terjadinya berbagai jenis komplikasi seperti: ketika mengenai mata menyebabkan retinopati. Mengenai jantu maka akan menyebabkan kemungkinan jantung coroner, gagal jantung kongestif, infark miokard. Dan ketika mengenai bagian otak maka akan menyebabkan stroke, enselovati hipertensi. Secara garis besar.

Menurut Junaedi dkk, pada tahun 2013, penanganan hipeertensi dapat dilakuakan dengan cara herbal yaitu dengan menggunakan camellia sinensis. Camellia sinensis merupakan siasat efektif untuk mencegah penyakit degenerative. Dalam setiap pucuk camellia sinensisi terkandung $30-40 \%$ polifenol yangmana khasiatnya sebagai antioksidan untuk mengurangi resiko terapapar jenis kanker system prostat, hati, payudara, katarak, serta pencernaan.

Menurut Syah, paga tahun 2006 menjelaskan, manfaat utama camellia sinensisi berasal dari kandungan senyawa polifenol. Kinerja enzim superoxside dismutase dalam tubuh dibantu oleh senya 
polifenol. Dimana radikal bebas dapat disingkirkan yang dihasilkan dari proses oksidasi dalam tubuh yang dapat memicu penyakit kardiovaskuler. Secra medis senyawa polifenol yang terkandung dalam camellia sinensis mempunyai berbagai khasiat diataranya mengurangi terjadinya kanker, cholesterol dalam drah, tumor, menjaga nafas dari bau busuk serta dapat mencegah tekanan darah tingi.

\section{METODE}

Riset ini menggunakan metode PreEksperiment Design dengan rancanan riset One Group Pretest-Posttest. Rancanga ini hanya menggunakan kelompok perlakuan. Riset ini bertujuan mengkaji data subjek penelitian berupa tekanan dara preintervensi setelah itu akan diperiksa ulang post-intervensi. Sebelum perlakuan akan diukur tekanan darah sebagai data preintervensi kemudian akan di ukur kembali setelah 15 hari sebagai data post-intervensi pemberian seduhan green tea. semua lanjut usai yang ada di Posbindu Anyelir Kampung Pakulonan Kabupaten Tangerang merupakan populasi dalam riset ini. lanjut usia merupakan sampel dalam riet ini, dimana lansia yang sedan menderita tekanan darah tinggi di Posbindu Anyelir
Kampung Pakulonan Kabupaten Tangerang.

Teknik yang digunakan dalam riset ini adalah total sampel dengan kriteria yang diinginkan peneliti sebagai berikut: merupakan lansia minimal usia 45 tahun yaitu usia pertengahan (middle age), sedan menderita hipertensi, sedang tidak mengkonsumsi obat anti hipertensi, bersedia menjadi responden, tidak menderita asama urat. Penelitian ini dilakukan di wilayah Posbindu Anyelir Kampung Pakulonan Kabupaten Tangerang pada bulan maret 2020 yang meliputi proses pengambilan data awal serta pengurusan perijinan penelitian. Dengan instrument pengumpulan data: Sphygmomanometer atau tensimeter aneroid/jarum, stetoskop, lembar observasi serta lembar checklist. Dengan bahan 2,5 gram camellia sinensisi yang diseduh dengan air panas dengan suhu $70^{\circ} \mathrm{C}$ selama 15 menit.

Uji Wilcoxon adalah uji statistic yang digunakan untuk menganlisa data dengan kemaknaan 95\% $(\alpha=0,05)$ SPSS seri 23 dengan bit 64 jenis software dari windows yang digunakan. 
Dewi Fitriani et al_Pengaruh Pemberian Seduhan Camellia Sinensis Terhadap Tekanan Darah Pada Lansia Dengan Hipertensi Di Posbindu Anyelir Kampung Pakulonan Kabupaten Tangerang

\section{HASIL}

Tabel 1. Distribusi Karakteristik Responden Berdasarkan Usia Di Posbindu Anyelir Kampung Pakulonan Kabupaten Tangerang. $(\mathrm{n}=35)$

\begin{tabular}{lll}
\hline Usia & $\mathrm{n}$ & $\%$ \\
\hline 45-59 Tahun & 16 & 45,7 \\
$60-74$ Tahun & 17 & 48,6 \\
$75-90$ Tahun & 2 & 5,7 \\
$>90$ Tahun & - & - \\
\hline Total & 35 & 100 \\
\hline
\end{tabular}

Berdasarkan tabel 1 menunjukan hampir dengan jumlah 16 responden $(45,7 \%)$, dan setengah responden yaitu usia tua dengan jumlah 17 responden (48,6\%), Hampir hampir tidak ada responden yaitu lanjut setengah responden yaitu usia pertengahan

Tabel 2. Distribusi Karakteristik Responden Berdasarkan Jenis Kelamin Di Posbindu Anyelir Kampung Pakulonan Kabupaten Tangerang ( $\mathrm{n}=35)$

\begin{tabular}{lll}
\hline Jenis Kelamin & $\mathrm{n}$ & $\%$ \\
\hline Laki-laki & 16 & 45,7 \\
Perempuan & 19 & 54,3 \\
\hline Total & 35 & 100 \\
\hline
\end{tabular}

Berdasarkan tabel 2 menunjukan bahwa $(54,3 \%)$, dan hampir setengah responden lebih dari setengah responden yaitu yaitu laki-laki dengan jumlah 16 responden perempuan dengan jumlah 19 responden (45,7\%).

Tabel 3. Distribusi Frekuensi Pengukuran Tekanan Darah Sistolik Pre Intervensi Seduhan Camellia Sinensis Pasien Hipertensi Di Posbindu Anyelir Kampung Pakulonan Kabupaten Tangerang $(\mathrm{n}=35)$

\begin{tabular}{lllllll}
\hline Variabel & Tekanan Darah & $\mathrm{n}$ & $\%$ & Mean & Min & Max \\
\hline \multirow{2}{*}{$\begin{array}{l}\text { Tekanan } \\
\text { Darah }\end{array}$} & Hipertensi Derajat $1.140-159 \mathrm{mmHg}$ & 22 & 62,8 & & & \\
\cline { 2 - 4 } Sistolik & Hipertensi Derajat 2. $160-179 \mathrm{mmHg}$ & 10 & 28,6 & & & \\
\cline { 2 - 4 } & Hipertensi Derajat $3 . \geq 180 \mathrm{mmHg}$ & 3 & 8,6 & & 140 & 187 \\
\cline { 2 - 4 } & Total & 35 & 100 & & & \\
\hline
\end{tabular}

Berdasarkan Tabel 3 menunjukan lebih dari setengah responden mengalami hipertensi derajat 1 dengan jumlah 22 responden
(62,8\%), hampir setengah responden mengalami hipertensi derajat 2 dengan jumlah 10 responden $(28,6 \%)$ dan 
sebagian kecil responden mengalami hipertensi derajat 3 dengan jumlah 3 responden $(8,6 \%)$.

Tabel 4. Distribusi Frekuensi Pengukuran Tekanan Darah Diastolik Pre Intervensi Seduhan Camellia Sinensis Pasien Hipertensi Di Posbindu Anyelir Kampung Pakulonan Kabupaten Tangerang $(\mathrm{n}=35)$

\begin{tabular}{|c|c|c|c|c|c|c|}
\hline Variabel & Tekanan Darah & $\mathrm{n}$ & $\%$ & Mean & Min & $\operatorname{Max}$ \\
\hline \multirow{7}{*}{$\begin{array}{l}\text { Tekanan } \\
\text { Darah } \\
\text { Diastolik }\end{array}$} & Optimal & 8 & 22,9 & \multirow{7}{*}{98,40} & \multirow{6}{*}{60} & \multirow{7}{*}{122} \\
\hline & Normal & 7 & 20 & & & \\
\hline & Tinggi-normal & 4 & 11,4 & & & \\
\hline & Hipertensi Derajat 1. 90-99 $\mathrm{mmHg}$ & 9 & 25,7 & & & \\
\hline & Hipertensi Derajat 2. 100-109 mmHg & 5 & 14,3 & & & \\
\hline & Hipertensi Derajat 3. $\geq 110 \mathrm{mmHg}$ & 2 & 5,7 & & & \\
\hline & Total & 35 & 100 & & & \\
\hline
\end{tabular}

Berdasarkan Tabel 4 menunjukan sebagian kecil responden hipertensi derajat 1 dengan jumlah 9 responden $(25,7 \%)$, sebagian kecil responden dalam kategori optimal dengan jumlah 8 responden $(22,9 \%)$, sebagian kecil responden kategori normal dengan jumlah 7 responden $(20 \%)$, sebagian kecil responden kategori hipertensi derajat 2 dengan jumlah
5 responden (14,3\%), sebagian kecil responden kategori tinggi-normal dengan jumlah 4 responden $(11,4 \%)$, dan hampir tidak ada responden kategori hipertensi derajat 3 dengan jumlah 2 responden $(5,7 \%)$.

Tabel 5. Distribusi Frekuensi Pengukuran Tekanan Darah Sistolik Post Intervensi Seduhan Camellia Sinensis Pasien Hipertensi Di Posbindu Anyelir Kampung Pakulonan Kabupaten Tangerang $(\mathrm{n}=35)$

\begin{tabular}{|c|c|c|c|c|c|c|}
\hline Variabel & Tekanan Darah & $\mathrm{n}$ & $\%$ & Mean & Min & $\operatorname{Max}$ \\
\hline \multirow{7}{*}{$\begin{array}{l}\text { Tekanan } \\
\text { Darah } \\
\text { Sistolik }\end{array}$} & Optimal & - & - & \multirow{7}{*}{149,06} & \multirow{7}{*}{130} & \multirow{7}{*}{181} \\
\hline & Normal & - & - & & & \\
\hline & Tinggi-normal & 11 & 31,4 & & & \\
\hline & Hipertensi Derajat 1. 140-159 mmHg & 15 & 42,8 & & & \\
\hline & Hipertensi Derajat 2. 160-179 mmHg & 7 & 20 & & & \\
\hline & Hipertensi Derajat 3. $\geq 180 \mathrm{mmHg}$ & 1 & 2,8 & & & \\
\hline & Total & 35 & 100 & & & \\
\hline
\end{tabular}

Berdasarkan Tabel 5.5 menunjukan hampir setengah responden mengalami hipertensi derajat 1 dengan jumlah 15 responden
(42,8\%), hampir setengah responden kategori tinggi-normal dengan jumlah 11 responden $(31,4 \%)$, sebagian kecil 
Dewi Fitriani et al_Pengaruh Pemberian Seduhan Camellia Sinensis Terhadap Tekanan Darah Pada Lansia Dengan Hipertensi Di Posbindu Anyelir Kampung Pakulonan Kabupaten Tangerang

responden mengalami hipertensi derajat 2 hipertensi derajat 3 dengan jumlah 1 dengan jumlah 7 responden (20\%) dan responden $(2,8 \%)$.

hampir tidak ada responden mengalami

Tabel 6 Distribusi Frekuensi Pengukuran Tekanan Darah Diastolik Post Intervensi

Seduhan Camellia Sinensis Pasien Hipertensi Di Posbindu Anyelir Kampung Pakulonan Kabupaten Tangerang $(\mathrm{n}=35)$

\begin{tabular}{|c|c|c|c|c|c|c|}
\hline Variabel & Tekanan Darah & $\mathrm{n}$ & $\%$ & Mean & Min & $\operatorname{Max}$ \\
\hline \multirow{7}{*}{$\begin{array}{l}\text { Tekanan } \\
\text { Darah } \\
\text { Diastolik }\end{array}$} & Optimal & 12 & 34,3 & \multirow{7}{*}{86,83} & \multirow{7}{*}{60} & \multirow{7}{*}{120} \\
\hline & Normal & 6 & 17,1 & & & \\
\hline & Tinggi-normal & 3 & 8,6 & & & \\
\hline & Hipertensi Derajat 1. 140-159 mmHg & 9 & 25,7 & & & \\
\hline & Hipertensi Derajat 2. $160-179 \mathrm{mmHg}$ & 3 & $8,6 \%$ & & & \\
\hline & Hipertensi Derajat $3 . \geq 180 \mathrm{mmHg}$ & 2 & 5,7 & & & \\
\hline & Total & 35 & 100 & & & \\
\hline
\end{tabular}

Berdasarkan Tabel 6 menunjukan hampir setengah responden kategori optimal dengan jumlah 12 responden $(34,3 \%)$, sebagian kcil responden mengalami hipertensi derajat 1 dengan jumlah 9 responden $(25,7 \%)$, sebagian kecil responden kategori normal dengan jumlah 6 responden $(17,1 \%)$, sebagian kecil responden kategori tinggi-normal dengan

Tabel 7. Distribusi Frekuesi Berdasarkan Mean Tekanan Darah Sistolik Dan Diastolik Pre Dan Post Intervensi Pada Lansia Dengan Hipertensi Di Posbindu Anyelir Kampung Pakulonan Kabupaten Tangerang ( $\mathrm{N}=35)$

\begin{tabular}{llll}
\hline & Mean & & \\
\hline & & Post test & $\begin{array}{l}\text { Mean } \\
\text { Pretest-posttest intervensi }\end{array}$ \\
\hline Sistolik & 156,40 & 149,06 & 152,73 \\
Diastolik & 89,40 & 86,83 & 88,11 \\
\hline
\end{tabular}


Berdasarkan Tabel 7. menunjukan tekanan darah sistolik rata-rata pre test intervensi camellia sinensisi yang diberikan adalah $156,40 \mathrm{mmHg}$ sedangkan post test intervensi $149,06 \mathrm{mmHg}$ terlihat perbedaan mean antara pengukuran tekanan darah sistolik pre test intervensi dan post test intervensi pemberian seduhan camellia sinensis yaitu $152,73 \mathrm{mmHg}$.
Untuk tekanan darah diastolik dengan mean pre test intervensi camellia sinensis adalah $89,40 \mathrm{mmHg}$ sedangkan post test intervensi $86,83 \mathrm{mmHg}$ terlihat perbedaan mean antara pengukuran tekanan darah sistolik pre test intervensi dan post test intervensi pemberian seduhan camellia sinensis yaitu $88,11 \mathrm{mmHg}$.

Tabel 8. Pengaruh Pemberian Seduhan Camellia Sinensisi Terhadap Tekanan Drah Pada Lansia Dengan Hipertensi Di Posbindu Anyelir Kampung Pakulonan Kabupaten Tangerang $(n=35)$

\begin{tabular}{llll}
\hline Tekanan Darah & & & Nila P-Value \\
\hline & Pretest Mean & Posttest Mean & \\
\hline Sistolik & 156,40 & 149,06 & 0,000 \\
Diastolik & 89,40 & 86,83 & 0,000 \\
\hline
\end{tabular}

Berdasarkan tabel 8 diatas menunjukan hasil analisa statistik uji Wilcoxon diperoleh data untuk tekanan darah sistolik sebelum pemberian seduhan camellia sinensis yaitu $156,40 \mathrm{mmHg}$, sedangkan unutk tekanan darah sistolik setelah diastolik setelah pemberian camellia sinensis yaitu $86,83 \mathrm{mmHg}$, dan di daptkan (P-Value $=0,000$ ).

Data berdasarkan uji wilcoxson dengan demikian dapat disimpulkan untuk tekanan darah sistolik dan diastolik dengan (Pvalue $=0,000)<(\alpha=0,05) \quad$ dapat pemberian seduhan camellia sinensis yaitu 149,06 $\mathrm{mmHg}$, dan di dapatkan nilai pvalue $=0,000$. Sedangkan untuk tekanan darah diastolik sebelum pemberian camellia sinensis yaitu $89,40 \mathrm{mmHg}$, sedangkan untuk tekanan darah diinterpretasikan $\mathrm{H}^{\mathrm{a}}$ diterima dan terdapat pengaruh pemberian seduhan camellia sinensis terhadap tekanan darah pada lansia dengan hipertensi Di Posbindu Anyelir Kampung Pakulonan Kabupaten Tangerang. 
Dewi Fitriani et al_Pengaruh Pemberian Seduhan Camellia Sinensis Terhadap Tekanan Darah Pada Lansia Dengan Hipertensi Di Posbindu Anyelir Kampung Pakulonan Kabupaten Tangerang

\section{PEMBAHASAN}

Penderita hipertensi dipengaruhi oleh umur karena semua fungsi organ mengalami penurunan terutama elastisitas arteri yang berhubungan dengan arterosklerosis (pengerasan dinding arteri) yang mana dapat memicu tekanan darah tinggi pada lanjut usia, didapatkan hasil dari penelitian ini sebanyak 16 responden (46\%) usia 4559 tahun.

Menurut Jasmarijal pada tahun 2011, menjelaskan ketika seseorang sudah mencapai usia 45 tahun lebih maka yang sering terjadi adalah penyakit hipertensi. Penyebabnya karena berhubungan dengan pengerasan dinding arteri akibat penuaan.

Menurut Bandiyah pada tahun 2009 dalam Artinawati pada tahun 2014, menjelaskan bahwa masalah pada proses penuaan diantaranya kekakuan jantung serta penebalan katup jantung dan penurnuan kerja jantung dalam memompa darah mengalami penurunan $15 \%$ ketika mencapai usia 20 tahun.

Penderita hipertensi dipengaruhi oleh jenis oragn vital, dimana lanjut usia dengan jenis organi vital wanita lebih beresiko menderita tekanan darah tinggi dari pada pria . diamna sesuai dengan penelitian yang dilakukan peneliti, dimana ditemukan jumlah responden wanita yang menderita hipertensi sebanyak 19 responden (54\%).

Menurut Aini dan Mahatidanar pada tahun 2017, menjelaskan bahwa dalam penelitiannya berdasarkan jenis kelamin, tekanan darah tinggi pada perempuan berkaitan dengan faktor hormonal ketika perempuan sudah mencapai umur 40 tahun keatas sudah masuk dalam masa menopause.

Menopause adalah faktor pemicu terjadinya hipertensi pada perempuan, dimana dapat menyebabkan kelainan fungsi dari ovarium yang lambat laun menghilang serta kadar estrogen menurun setelah menopause. Dengan demikian dapat mengakibatkan kadar kolesterol serta low density lipoprotein. Sedangkan reseptor LDL mengalami pengurangan. Dengan demikian akan mengakibatkan peningkatan tekanan darah (Ganiswarna, 2003 dalam Aini dan Mahatidanar, 2017).

Ciri seseorang yang mempengaruhi timbulnya hipertensi adalah jenis kelamin, 
individu yang mengalami hipertensi seperti perempuan yang mengalami menopause dimana mempunyai tekanan darah sama dengan atau lebih besar 140/90 mmHg yaitu $50-60 \%$. Perbedaan struktur organ serta hormone pada setiap jenis kelamin, begitupula juga pada wanita dan pria. Yang berkaitan dengan tekanan darah tinggi, resiko lebih besar terjadi pada pria dikarenakan morbiditas dan mortilitas kardiovaskular, sedangkan ketika usia sudah mencapai 50 tahun hal ini yang terjadi pada perempuan yang mengakibatkan penyakit tekanan darah tinggi (Susilo, 2011 dalam Wijayathi, 2018).

Dari 35 responden penelitian. responden paling banyak mengalami hipertensi derajat 1 berjumlah 22 responden $(62,8 \%)$ dan tekanan darah diastolik menderita hipertensi derajat 1 dengan jumlah 9 responden $(25,7 \%)$, tekanan darah rata-rata sistolik sebelum perlakuan $156,40 \mathrm{mmHg}$ dan tekanan darah rata-rat diastolik sebelum perlakuan 89,40 mmHg. Dengan hasil sistolik rata-rata setelah perlakuan 149,06 $\mathrm{mmHg}$ dan tekanan darah rata-rat diastolik setelah perlakuan $86,83 \mathrm{mmHg}$.
Setelah dilakukan pemberian seduhan camellia sinensis selama 15 hari berturutturut dari 35 responden menunjukan bahwa tekanan darah rata-rata sistolik pre serta post intervensi sebesar 152,73 $\mathrm{mmHg}$, sementara untuk tekanan darah rata-rata diastolik pre serta post intervensi 88,11 $\mathrm{mmHg}$.

Setelah dilakukan pemberian seduhan camellia sinensis selama 15 hari berturutturut didaptan responden paling banyak mengalami hipertensi derajat 1 sebanyak 15 responden $(42,8 \%)$ dari 35 responden penelitian. Dengan rata-rata sistolik setelah perlakuan 149,06 mmHg dan tekanan darah rata-rata diastolik post intervensi yaitu $86,83 \mathrm{mmHg}$. Terjadi penurunan derajat hipertensi pada 35 responden yang mengalami peningkatan tekanan darah yang dikarenan stress, usia, konsumsi garam (diet) tidak terkontrol dan gaya hidup (merokok).

Camellia sinensis merupakan terapi herbal yang baik untuk penderita hipertensi karena kandungan polifenol, yang dapat mencegah radikal bebas yang bisa menghambat aliran darah adalah polifenol. 
Dewi Fitriani et al_Pengaruh Pemberian Seduhan Camellia Sinensis Terhadap Tekanan Darah Pada Lansia Dengan Hipertensi Di Posbindu Anyelir Kampung Pakulonan Kabupaten Tangerang

Menurut Mulyani dkk pada tahun 2017, adalah penelitian yang sejalan dengan penelitian ini. Dimana hasil dari penelitian ini diperoleh rata-rata penurunan tekanan darah sistolik 9,47 mmHg $\mathrm{p}<0,005$.

Menurut Syah pada tahun 2006, menjelaskan kandungan $30-40 \%$ dalam teh adalah polifenol atau sering dikenal dengan sebutan katekin. Antioksidan yang kuat lebih kuat dari beta karoten dan vitaminC,E adalah katekin. Kinerja enzim superoxsidase dismutasi kinerjanya dibantu oleh senyawa polifenol yang berfungsi menyingkirkan radikal bebas. Proses oksidasi di dalam tubuh sangat berbahaya bagi keshatan karena menimbulkan radikal bebas dimana akan menimbulkan penyakit serta menghambat aliran darah. Dengan terdaptnya senyawa polifenol di dalam teh maka di percaya dapat mencegah tekanan darah tinggi.

Didalam teh juga terdapat kandungan flavonoid, sayur-sayura secara alamih terdapat kandungan plavonoid. Begitu juga anggur dan teh yang terdapat kandungan plavonoid. Stress lingkungan dapat diberikan perlindungan oleh tanaman yang mengandung plavonoid. (Syah, 2006)

\section{KESIMPULAN}

Usia 60-75 tahun yang paling banyak menderita hipertensi $(48,6 \%)$ dengan jenis kelamin yaitu perempuan sebanyak 19 responden $(54,3 \%)$. Berdasarkan tekanan darah pre-intervensi untuk tekanan darah sitolik paling banyak hipertensi derajat 1 sebanyak 22 responden $(62,8 \%)$ dan untuk tekanan darah diastolik hipertensi derajat 1 sebanyak 9 responden $(25,7 \%)$. Sedangkan berdasrkan tekanan darah post-intervensi untuk tekanan darah sistolik palin banyak hipertensi derajat 1 sebanyak 15 responden $(42,8 \%)$ dan tekanan darah diastolik paling banyak tekanan darah optimal sebanyak 12 responden (34,3\%), dengan rata-rata penurunan tekana darah sistolik pre dan post intervensi sebesar 152,73 $\mathrm{mmHg}$ sedangkan untuk rata-rata tekanan darah diastolik pre dan post intervensi sebesar 88,11 mmHg. Terdapat pengaruh pemberian seduhan camellia sinensis terhadap tekanan darah pada lansia dengan hipertensi di posbindu anyelir kampung pakulonan kabupaten tangerang hasil uji SPSS dengan uji Wilcoxon (P-Value = $0,000<\alpha=0,05)$. Diharapkan dapat dijadiakn terpai herbal untuk mengontrol 
tekanan darah pada penderita hipertensi agar tetaap normal dan stabil.

\section{DAFTAR PUSTAKA}

Artinawati, Sri. Asuhan Keperawatan Gerontik. In Media, Bogor; 2014.

Astari, Ni. Pengaruh Pemberian Teh Hijau Terhadap Penurunan Kadar Kolesterol Pada Lansia Awal (4546) Tahun Di Dusun Ngudirejo Desa Ngudirejo [Online Jurnal]. STIKes ICME; 2017. [Diakses.09.Januari.2020].

Availabel at: http://repo.stikesicmjbg.ac.id/145/1/ Skripsi\%20Ni\%20Made\%20Sinta.p df.

Aini, Nurul, Tanto Hariyanto, dan Vita Maryah Ardiyani. Perbedaa Tekanan Darah Sebelum Dan Sesudah Dilakukan Terapi Musik Klasik (Mozart) Pada Lansia Hipertensi Stadium 1 Di Desa Donowarih Karangploso Malang [Online Jurnal]. Malang Jawa Timur; 2017 [Diakses.12.Februari.2020]. Availabel at : https://publikasi.unitri.ac.id/index.p hp/fikes/article/view/566/451

Aini, Rahimatul. Pengaruh Pemberian Madu Terhadap Perubahan Tekanan Darah Pada Penderita ipertensi Di Wilayah Kerja UPK Puskesmas Khatulistiwa Kecamatan Pontianak Utara [Online Jurnal]. Universitas Tanjungpura Surakarta; 2016 [Diakses 09 Januari 2020].
Anugrianti, Tri. Pengaruh Senam Lansia Terhadap Penurunan Tekanan Darah Pada Penderita Hipertensi Di Puskesmas Bakti Jaya Tangerang Selatan [Skripsi]. STIKes Widya Dharma Husada; 2018.

Dinas kesehatan Provinsi Banten. Profil Kesehatan Provinsi Banten; 2018. [Diakses 11 Januari 2020]. Availabel at: https://dinkes.bantenprov.go.id

Dinkes Provinsi Banten. Profil Kesehatan Provinsi Banten; 2018. [Diakses 13 januari 2020]. Availabel at: https://dinkes.bantenprov.go.id

Hudan, Nurarif \& Hardi, Kusuma. Aplikasi Asuan KeperawatanBerdasarkan Diagnosa Medis Nanda Nic-Noc. Edisi Revisi Jilid 2. MediaAction. Jogjakarta; 2015.

Junaedi, Edi dkk. Hipertensi Kandas Berkat Herbal. FMedia. Jakarta; 2013.

Khaolya, Srie. Faktor-faktor Yang Berhubungan Dengan Kejadian Hipertensi Pada Wanita Umur >45 Tahun Di Desa Merak RT02/RW02 Kecamatan Sukamulya Kabupaten Tangerang [Skripsi]. STIKes Widya Dharma Husada Tangerang; 2017.

Kementrian Kesehatan Republik Indonesai. Data Dan Informasi Profile Kesehatan Indonesia; 2017. [Diakses 11 Januari 2020]. Availabel at: www.depkes.go.id.

Kementrian Kesehatan Republik Indonesai. Data Dan Informasi Profile Kesehatan Indonesia; 2018. 
Dewi Fitriani et al_Pengaruh Pemberian Seduhan Camellia Sinensis Terhadap Tekanan Darah Pada Lansia Dengan Hipertensi Di Posbindu Anyelir Kampung Pakulonan Kabupaten Tangerang

[Diakses 11 Januari 2020]. Vailabel at: www.depkes.go.id.

Mahartidanar, Andhika. Pengaruh Musik Klasik Terhadap Penurunan Tekanan Darah Pada Lansia Penderita Hipertensi [Online Jurnal]. Lampung; 2016. [Diakses 04 Februari 2020]. Availabel at: http://digilib.unila.ac.id/21703/3/SK RIPSI\%20TANPA\%20BAB\%20PE MBAHASAN.pdf.

Mulyani, Sri. Pengaruh Pemberian Teh Hijau Terhadap Tekanan Darah Pada Penderita Hipertensi, Politeknik Kesehatan Kemenkes Aceh [Online Jurnal], Aceh Besar; 2019 [Diakses 10 Januari 2020].

Nur, Andi. Taklukan Penyakit Deangan Teh Hijau. AgroMedia Pustaka. Depok; 2006.

Notoatmodjo, Sukidjo. Metodologi Penelitian Kesehatan. Rineka Cipta. Jakarta; 2018.

Puspitasari, Tika. Pengaruh Pemberian Buah Pisang Ambon Terhadap Penurunan Tekanan Darah Pada Penderita Hipertensi Di Wilayah Kerja Puskesmas Bakti Setu Kota Tangerang Selatan [Skripsi]. STIKes Widya Dharma Husada; 2018.

Rahayuningsih, Dwi. Pengaruh Suhu Dan Waktu Penyeduhan Teh Celup Terhadap Kadar Kafein [Online Jurnal]. Universitas Muhamadiah Surakarta; 2014 [Diakses 05 Januari 2020].
Rofi'ie, Imam. Ragam Menu Sehat Untuk Penderita Hipertensi. Wardi. Yogyakarta; 2010.

Sandu, Siyoto dan Muhit, Abdul. Keperawatan Gerontik. Andi. Yogyakarta; 2016.

Sopiyudin, M. Statistik Untuk Kesehatan Dan Kedokteran. Epid Indonesia. Jakarta; 2014.

Sugiyono. Metodologi Penelitian Kuantitatife Kualitatife dan R\&D. Alfabeta. Bandung; 2016. 